\title{
Occlusal characteristics and orthodontic treatment need in Black adolescents in Salvador/BA (Brazil): An epidemiologic study using the Dental Aesthetics Index
}

\author{
Arthur Costa Rodrigues Farias ${ }^{1}$, Maria Cristina Teixeira Cangussu², Rogério Frederico Alves Ferreira ${ }^{3}$, Marcelo de Castellucci ${ }^{4}$
}

Objective: The objective of this article is to evaluate the need of orthodontic treatment, prevalence and severity of the malocclusions in individuals of black ethnicity in a representative sample of schoolchildren of the city of Salvador/Brazil, as well as to verify if the malocclusion was affected by socio-demographic conditions such as age and gender. Methods: The reference population was constituted of schoolchildren with age between 12 and 15 years, enrolled in public and private schools. The malocclusion was evaluated in 486 students of black ethnicity, with ages varying from 12 to 15 years, selected in random sample in multiple stages. The adopted significance level was $1 \%$ and the power of the test was $90 \%$. A questionnaire registering demographic characteristics was filled out by each individual. The Dental Aesthetics Index (DAI) was used by previously calibrated examiners (kappa 0.89), according to criteria of the World Health Organization. Results: It was verified that most of the individuals ( $76 \%$ ) had little or any need for orthodontic treatment. About $24 \%$ showed a condition of severe malocclusion, culminating in a vital need for orthodontic treatment. The main occlusal characteristics found in the group with high need of orthodontic treatment were dental crowding and accentuated overjet. The age was positively related to the improvement of the maxillary overjet and to the presence of crowding. Conclusion: The development of public politics that aim the insertion of orthodontic treatment among the procedures of health programs, with the implementation and development of specialized centers, is fundamental.

Keywords: Malocclusion. Orthodontics. Esthetics. Dental. Dental Health Surveys.

Objetivo: averiguar a necessidade de tratamento ortodôntico, prevalência e severidade das más oclusões em indivíduos negros numa amostra representativa de escolares da cidade de Salvador/BA (Brasil), além de determinar se as más oclusões eram afetadas por condições sociodemográficas como idade e sexo. Métodos: o desenho epidemiológico foi transversal, e a população de referência se constituiu de escolares com idades entre 12 e 15 anos, matriculados em escolas de primeiro e segundo graus, públicas e privadas. Participou do estudo um total de 486 indivíduos sorteados em amostra probabilística em múltiplo estágio. O nível de significância adotado foi de $1 \%$ e o poder do teste foi de 90\%. Aos participantes foram aplicados questionários registrando características demográficas e, depois, avaliados por examinadores previamente calibrados (Kappa 0,89), utilizando-se o Índice de Estética Dentária (IED) segundo critérios da Organização Mundial de Saúde. Resultados: constatou-se que a maioria dos indivíduos (76\%) observados nesse estudo possuía pouca ou nenhuma necessidade de tratamento ortodôntico. Cerca de 24\% apresentaram uma condição de má oclusão severa, acarretando uma imprescindível necessidade de tratamento ortodôntico. As principais características oclusais encontradas no grupo com maior necessidade de tratamento ortodôntico foram apinhamento dentário e overjet maxilar acentuado. A idade foi positivamente relacionada com a melhora do quadro do overjet maxilar e com a presença de apinhamento dentário. Conclusão: torna-se fundamental o desenvolvimento de políticas públicas que objetivem a inserção do tratamento ortodôntico entre os procedimentos dos programas de saúde, com a implementação e desenvolvimento de centros especializados.

Palavras-chave: Má oclusão. Ortodontia. Prevalência. Estética dentária. Levantamentos de Saúde Bucal.

\footnotetext{
${ }^{1}$ Orthodontist of the Unit of Face Deformities of UFRN.

${ }^{2}$ Associate professor, Department of Social and Pediatric Dentistry, UFBA

${ }^{3}$ Associate professor of Orthodontics, UFBA

${ }^{4}$ Professor, Specialization Course in Orthodontics and Facial Orthopedics, School of Dentistry, UFBA
}

» The author reports no commercial, proprietary or financial interest in the products or companies described in this article.
How to cite this article: Farias ACR, Cangussu MCT, Ferreira RFA, Castellucci M. Occlusal characteristics and orthodontic treatment need in black adolescents in Salvador/BA (Brazil): An epidemiologic study using the Dental Aesthetics Index. Dental Press J Orthod. 2013 Jan-Feb; 18(1):34.el-8.

\footnotetext{
Submitted: October 21, 2008 - Revised and accepted: August 6, 2009 Contact address: Arthur Costa Rodrigues Farias Faculdade de Odontologia da Universidade Federal da Bahia Av. Araújo Pinho, 62 - Canela - CEP: 40.110-060 - Salvador/BA - Brazil E-mail: arthurcrfarias@hotmail.com
} 


\section{INTRODUCTION}

Brazil, differently from many other countries, has a population characterized by a large ethnic miscegenation, whose occlusal characteristics have been epidemiologically considered by some studies. ${ }^{12,26,29}$ Regarding morphological researches, there seems to be consensus among the orthodontists that some data which indicate normality may vary in the populations from different geographic regions, or in different ethnic groups.

It must also be emphasized the importance of the association of the severity of malocclusions with several factors such as dental caries, early tooth loss and periodontal diseases.

Associated with the ethnic aspects, the socioeconomic factors must also be considered, as according to some authors, ${ }^{15,18,22}$ the occlusion must be studied in its social context, giving importance not only to the physical consequences of its bad development, but also to the negative impact it has on the social wellbeing.

In Brazil, the variable "ethnicity" is related to some health problems, including some of oral health, which are often influenced by differences in socioeconomic conditions..$^{12,25}$ One of the cities that best fits this situation of ethnic miscellany and socioeconomic disparity is Salvador, in Bahia, where the black ethnicity is the most affected by problems arising from this situation, a fact which can be noticed mainly in the poorest - or in those of social deprivation - areas of the city.

According to Perin's conception, ${ }^{21}$ with the evolution of Dentistry, Orthodontics is in a challenging situation, considering that the concern towards the extension of services to the community gradually becomes greater. So, it becomes necessary to know the epidemiological situation of the malocclusions for the planning and rationing of the necessary (human and financial) resources for the efficient provision of orthodontic treatment for the neediest population.

Diagnosis in orthodontics is based primarily on the classification of deviations from normality, and the measure of changes and deviations in relation to it depends on the methods used and the trial of examiners. ${ }^{23}$ That is, the traditional orthodontic diagnosis is qualitative, not being suitable for use in public health, since the quantification of problems is the most ap- propriate solution to get to know the problem in a collective perspective, identify specific factors and subsidize the planning and evaluation of actions as well as the use and distribution of resources. As a result of this, many quantitative methods that are able to classify or evaluate the deviations from normal occlusion have been developed over the past 50 years, allowing a service which is a priority to individuals who show the most severe malocclusions.

The diversity of occlusal indices in the literature is very vast, from those who classify the malocclusions by diagnosis to those who establish the need and complexity of orthodontic treatment, such as: the Treatment Priority Index (TPI), the Summers Occlusal Index, Draker's Handicapping Labio-lingual Deviations Index (HLD), the Handicapping Malocclusion Assessment Record (HMAR), the Index of Orthodontic Treatment Need (IOTN) and the Dental Aesthetic Index (DAI). ${ }^{6,7,10,13,23,27}$ All of these indices compile a set of data about malocclusion and expose a final numeric or alphanumeric value that can classify the occlusal situation at a level of severity and of treatment indication.

The Dental Aesthetic Index (DAI) was recommended by the WHO in $1997^{30}$ to assess the severity and need for treatment of malocclusions. The DAI was developed in 1986 at the University of Iowa (USA), based on perceptions of dental esthetics in the United States. It identifies ten occlusal changes, considering dental absence, space and occlusion, resulting mathematically in scores, with weights based on their relative importance according to socially defined esthetic standards. Since it is based on scores of the cases provided by the DAI, in general one may consider it one of the most appropriate criteria to prioritize needs of orthodontic treatment, presenting a clinical approach with an epidemiological character. ${ }^{8}$

In this context, the objective of this study was to identify the main occlusal characteristics of the black ethnicity from a representative sample of the population of schoolchildren in Salvador, in Brazil, and determine the need for orthodontic treatment in this group according to age and gender, in order to provide a solid basis for the estimates of current conditions of oral health of the population and, thus, produce reliable basic data that can be used to develop oral health programs. 


\section{MATERIAL AND METHODS}

The sample for this survey was drawn from a study conducted by the Institute of Public Health and the Dentistry College of the Federal University of Bahia.

A transversal epidemiological design was used, and the reference population consisted of schoolchildren aged between 12 and 15 years $(n=220300)$ enrolled in public and private, first and second degree schools in Salvador, Bahia, in 2005. These ages were selected because the World Health Organization (WHO) ${ }^{18}$ considers the age of 12 years as a comparison age and international surveillance of oral diseases, and the age of 15 years as the one at which the prevalence of decay is more significant, since permanent teeth are exposed from three to nine years in the oral environment.

This study population consisted of 2100 school born in Bahia (42.5\% boys and 57.5\% girls), drawn through a multistage probabilistic sample, whose primary sampling units represent the registration of public and private schools of the city, provided by the Ministry of Education. Seventy-two educational establishments (10\% of total) were pre-stratified by the Health District and randomly selected, in obedience to the proportionality between public and private schools of basic education and high school. To calculate the sample, data of population of the proportion of malocclusion at 12 years of age with an estimated prevalence of $10 \%$ at the highest severity were used. The level of significance was set at $1 \%$ and the power of the test was $90 \%$. The number of individuals classified as belonging to a black ethnic group was 486 .

The person responsible for each selected student signed the term consent for the study, which was approved by the Committee of Ethics in Research of ISC / UFBA, following the requirements of the Resolution 196/96 of the National Health.

For the categorization of black individuals, the research adopted the classification used by the Brazilian Institute of Geography and Statistics (2004), taking into account the predominant physical features.

The subjects were assessed by means of the Dental Aesthetic Index (DAI) in accordance with the methodology proposed by the World Health Organization. ${ }^{30}$

Periodontal catheters from WHO and disposable wooden spatulas were used for the separation of cheeks and lips.
All data of the malocclusions were collected by six examiners previously calibrated in a pilot study. The overall percentage of agreement was $98.16 \%$, and the kappa 0.89 , with the worst agreement between the examiners equal to $85.30 \%$. Both indicators were calculated from the average of the two examiners. An agreement considered satisfactory by $\mathrm{WHO}^{18}$ for epidemiological surveys on oral health was achieved. Exclusion criteria were:

" Those students who were under orthodontic treatment.

"Students who had already undergone some orthodontic treatment.

Every component registered was multiplied by its corresponding coefficient. The products were summed and added to the constant for the final value of DAI to be obtained (Table 1).

The levels of severity and need for orthodontic treatment can be classified according to the final score of: a) no abnormality or mild malocclusion with little or no need for treatment $(\leq 25)$, b) defined malocclusion in need of elective treatment (26 to 30$), c$ ) severe malocclusion with highly desirable indication of treatment (31 to 35$)$ and d) disabling or very severe malocclusion with essential need for treatment (> 36).

Table 1 - Values and data from regression standard equation of DAI. (Source: Cons et $a l,{ }^{8}$ 1986).

\begin{tabular}{|c|c|c|}
\hline Conditions & Components of DAI & Weight \\
\hline 1 & Number of visible missing teeth & 6 \\
\hline 2 & $\begin{array}{l}\text { Crowding on incisal segments: } \\
0=\text { no crowding, } 1 \text { = } 1 \text { segment with crowding, } \\
2=2 \text { segments with crowding }\end{array}$ & 1 \\
\hline 3 & $\begin{array}{l}\text { Spacing on incisal segments: } \\
0=\text { no spacing, } 1 \text { = } 1 \text { segment with spacing, } \\
2=2 \text { segments with spacing }\end{array}$ & 1 \\
\hline 4 & Median spacing in $\mathrm{mm}$ & 3 \\
\hline 5 & Greater maxillary anterior misalignment in $\mathrm{mm}$ & 1 \\
\hline 6 & Greater mandibular anterior misalignment in $\mathrm{mm}$ & 1 \\
\hline 7 & Maxillary overjet in mm & 2 \\
\hline 8 & Mandibular overjet in $\mathrm{mm}$ & 4 \\
\hline 9 & Anterior open bite in $\mathrm{mm}$ & 4 \\
\hline 10 & $\begin{array}{l}\text { Molar relationship; greater deviation from normal } \\
\text { to mesial or to distal: } 0=\text { normal, } 1=1 / 2 \text { cusp to } \\
\text { mesial or to distal, } 2=1 \text { or more cusps to mesial } \\
\text { or to distal }\end{array}$ & 3 \\
\hline 11 & CONSTANT & 13 \\
\hline & Total & $\begin{array}{c}\text { Score } \\
\text { DAI }\end{array}$ \\
\hline
\end{tabular}


Data were entered in the spreadsheet Microsoft Excel $^{\circledR} 2003$ and subsequently exported and analyzed using SPSS 10.0 for Windows. For purposes of analysis, the severity of malocclusion and need for orthodontic treatment were dichotomized into: mild malocclusion and little need for treatment, and, severe malocclusion and desirable treatment, with set at the score of 30 . The level of significance for all tests was $\mathrm{p}<0.05$.

\section{RESULTS}

From the 486 black individuals, 236 (48.6\%) were male and, 250 (51.4\%), female. The average age of subjects examined was 13.5 years $(\mathrm{SD}=1.1)$, with a median of 14 . Most individuals (26.5\%) were aged 15 years.

It can be statistically measured that male individuals from the age of 15 years have a lower need for orthodontic treatment than the others $(\mathrm{p}<0.05)$. The distribution of data according to age, sex and need for treatment is found in Table 2 .

With regard to the degree of severity of occlusal condition, two subjects had the more socially acceptable condition, each with a score of 13 . Only one individual had the highest severity score (69). The average final value of DAI for the entire sample was 26.28 $(\mathrm{SD}=7.87)$, being $26.01(\mathrm{SD}=7.78)$ for males and $26.52(\mathrm{SD}=7.96)$ for females. From the total sample, $61 \%$ showed a final score equal to or less than average.
It was observed in 76\% $(\mathrm{n}=369)$ a low need for orthodontic treatment, with a maximum score of 30 , which can be seen in Figure 1. On the other hand, $24 \%(n=117)$ of the group studied had severe malocclusion, with a high need for orthodontic treatment, where the scores were above 31 (Fig 1).

Tables 3 and 4 respectively show the distribution of DAI components according to the classification of the need for treatment and age. The first sub-category within each component characterizes a condition of normal occlusion. ${ }^{7}$ Dental crowding is one of the occlusal characteristics that most appear $(67.5 \%)$ in the group with high need for orthodontic treatment, and their presence increases with age. However, this was the only homogeneous condition in different degrees of severity. In all other components of DAI, like strong maxillary overjet (65\%), spacing (43.6\%) and open bite (40.2\%), we observed an increase in the presence and severity, being these differences statistically significant.

Testing the difference between the values of the various components of DAI between the two age groups (grouped for analysis in 1213 and 1415), the existence of an association between age, the presence of missing teeth and overjet was observed, when the population of younger individuals possessed a greater number of missing teeth and larger overjet. A significant increase in dental crowding with age was also observed.

Table 2 - Number and percentage distribution of individuals according to age, need for treatment and gender. Salvador, BA, 2004.

\begin{tabular}{|c|c|c|c|c|c|c|c|c|c|}
\hline \multirow{3}{*}{ Gender } & \multirow{3}{*}{ Treatment need } & \multicolumn{8}{|c|}{ Age (years) } \\
\hline & & \multicolumn{2}{|c|}{12} & \multicolumn{2}{|c|}{13} & \multicolumn{2}{|c|}{14} & \multicolumn{2}{|c|}{15} \\
\hline & & n & $\%$ & n & $\%$ & n & $\%$ & $n$ & $\%$ \\
\hline \multirow{2}{*}{ Male } & Low & 36 & 70.5 & 37 & 64.9 & 42 & 71.2 & 64 & 92.7 \\
\hline & High & 15 & 29.5 & 20 & 35.1 & 17 & 28.8 & 5 & 7.3 \\
\hline \multirow{2}{*}{ Female } & Low & 49 & 80.3 & 51 & 72.8 & 44 & 74.6 & 46 & 76.6 \\
\hline & High & 12 & 19.7 & 19 & 27.2 & 15 & 25.4 & 14 & 23.3 \\
\hline
\end{tabular}

${ }^{*} p>0.05(p=0.001$ for the 15 years) 
Table 3 - Number and percentage distribution of the variables according to the need for treatment. Salvador, BA, 2004.

\begin{tabular}{|c|c|c|c|c|c|c|}
\hline \multirow{3}{*}{ Condition } & & \multicolumn{4}{|c|}{ Treatment need } & \multirow{3}{*}{ p value } \\
\hline & & \multicolumn{2}{|c|}{ None/Elective } & \multicolumn{2}{|c|}{ Highly desirable/ Indispensable } & \\
\hline & & n & $\%$ & n & $\%$ & \\
\hline \multirow{2}{*}{ Missing teeth } & 0 & 362 & 98.1 & 100 & 85.5 & \multirow{2}{*}{0.000} \\
\hline & $\geq 1$ & 7 & 1.9 & 17 & 14.5 & \\
\hline \multirow{2}{*}{ Segments with crowding } & 0 & 202 & 54.7 & 38 & 32.5 & \multirow{2}{*}{0.785} \\
\hline & $1-2$ & 167 & 45.3 & 79 & 67.5 & \\
\hline \multirow{2}{*}{ Segments with spacing } & 0 & 240 & 65 & 66 & 56.4 & \multirow{2}{*}{0.000} \\
\hline & $1-2$ & 129 & 35 & 51 & 43.6 & \\
\hline \multirow{2}{*}{ Interdental spacing in mm } & 0 & 291 & 78.9 & 80 & 68.4 & \multirow{2}{*}{0.000} \\
\hline & $>0$ & 78 & 21.1 & 37 & 31.6 & \\
\hline \multirow{2}{*}{ Anterior maxillary misalignment in $\mathrm{mm}$} & $0-1$ & 292 & 79.1 & 61 & 52.1 & \multirow{2}{*}{0.000} \\
\hline & $>1$ & 77 & 20.9 & 56 & 47.9 & \\
\hline \multirow{2}{*}{ Anterior mandibular misalignment in $\mathrm{mm}$} & $0-1$ & 328 & 88.9 & 81 & 69.2 & \multirow{2}{*}{0.000} \\
\hline & $>1$ & 41 & 11.1 & 36 & 30.8 & \\
\hline \multirow{2}{*}{ Maxillary overjet in $\mathrm{mm}$} & $0-2$ & 210 & 56.9 & 41 & 35 & \multirow{2}{*}{0.000} \\
\hline & $>2$ & 159 & 43.1 & 76 & 65 & \\
\hline \multirow{2}{*}{ Mandibular overjet in $\mathrm{mm}$} & 0 & 358 & 97 & 104 & 88.9 & \multirow{2}{*}{0.000} \\
\hline & $>0$ & 11 & 3 & 13 & 11.1 & \\
\hline \multirow{2}{*}{ Open bite in $\mathrm{mm}$} & 0 & 351 & 95.1 & 70 & 59.8 & \multirow{2}{*}{0.000} \\
\hline & $>0$ & 18 & 4.9 & 47 & 40.2 & \\
\hline \multirow{2}{*}{ Molar cusps relationship } & Normal & 236 & 64 & 33 & 28.2 & \multirow{2}{*}{0.018} \\
\hline & Abnormal & 133 & 36 & 84 & 71 & \\
\hline
\end{tabular}

Table 4 - Number and percentage of variables according to age. Salvador, BA, 2004.

\begin{tabular}{|c|c|c|c|c|c|c|}
\hline \multirow{3}{*}{ Condition } & & \multicolumn{4}{|c|}{ Age (years) } & \multirow{3}{*}{ p value } \\
\hline & & \multicolumn{2}{|c|}{$12-13$} & \multicolumn{2}{|c|}{$14-15$} & \\
\hline & & $n$ & $\%$ & $n$ & $\%$ & \\
\hline \multirow{2}{*}{ Missing teeth } & 0 & 221 & 92.5 & 241 & 97.6 & \multirow{2}{*}{0.008} \\
\hline & $\geq 1$ & 18 & 7.5 & 6 & 2.4 & \\
\hline \multirow{2}{*}{ Segments with crowding } & 0 & 124 & 51.9 & 116 & 47 & \multirow{2}{*}{0.160} \\
\hline & $1-2$ & 115 & 48.1 & 131 & 53 & \\
\hline \multirow{2}{*}{ Segments with spacing } & 0 & 149 & 62.3 & 157 & 63.6 & \multirow{2}{*}{0.427} \\
\hline & $1-2$ & 90 & 37.7 & 90 & 36.4 & \\
\hline \multirow{2}{*}{ Interdental spacing in mm } & 0 & 180 & 75.3 & 191 & 77.3 & \multirow{2}{*}{0.339} \\
\hline & $>0$ & 59 & 24.7 & 56 & 22.7 & \\
\hline \multirow{2}{*}{ Anterior maxillary misalignment in mm } & $0-1$ & 172 & 72 & 181 & 73.3 & \multirow{2}{*}{0.412} \\
\hline & $>1$ & 67 & 28 & 66 & 26.7 & \\
\hline \multirow{2}{*}{ Anterior mandibular misalignment in $\mathrm{mm}$} & $0-1$ & 197 & 82.4 & 212 & 85.8 & \multirow{2}{*}{0.183} \\
\hline & $>1$ & 42 & 17.6 & 35 & 14.2 & \\
\hline \multirow{2}{*}{ Maxillary overjet in mm } & $0-2$ & 115 & 48.1 & 136 & 55.1 & \multirow{2}{*}{0.075} \\
\hline & $\geq 2$ & 124 & 51.9 & 111 & 44.9 & \\
\hline \multirow{2}{*}{ Mandibular overjet in mm } & 0 & 225 & 94.1 & 237 & 96 & \multirow{2}{*}{0.232} \\
\hline & $>0$ & 14 & 5.9 & 10 & 4 & \\
\hline \multirow{2}{*}{ Openbite in mm } & 0 & 209 & 87.4 & 212 & 85.8 & \multirow{2}{*}{0.348} \\
\hline & $>0$ & 30 & 12.6 & 35 & 14.2 & \\
\hline \multirow{2}{*}{ Molar cusps relationship } & Normal & 130 & 54.4 & 139 & 56.3 & \multirow{2}{*}{0.372} \\
\hline & Abnormal & 109 & 45.6 & 108 & 43.7 & \\
\hline
\end{tabular}




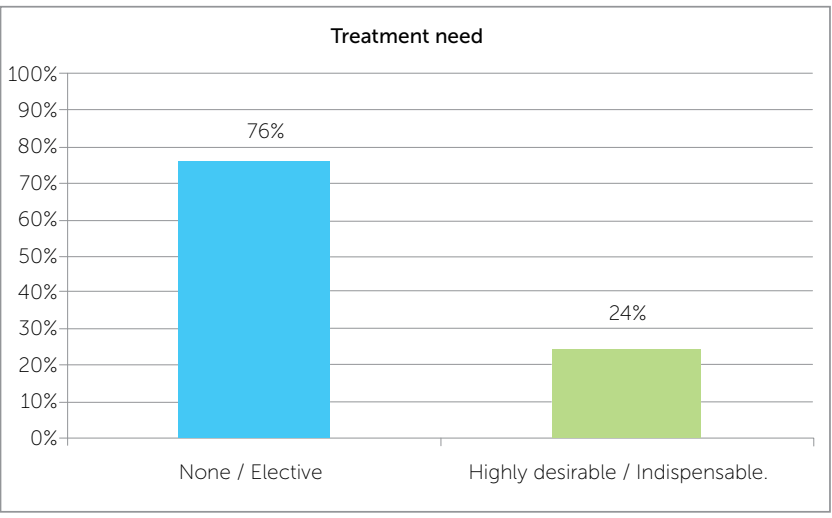

Figure 1 - Numerical and percentual distribution of individuals from Back ethnicity, according to the treatment need. Salvador, BA. 2004.

\section{DISCUSSION}

The indices used to assess need for orthodontic treatment ensure that individuals with similar needs have the same priority degree. In addition, the indices work as a communication tool for orthodontists, patients and those responsible for the patients. ${ }^{2,3,11,23}$

However, no index is universally accepted as a means of measuring all aspects of need of orthodontic treatment of individuals or populations. It thus becomes very complicated to elaborate an index that takes into account all circumstances of malocclusions and can also be used consistently by non-specialists in orthodontics. In addition, perceptions of malocclusion may differ between countries and cultures, as well as between age groups, so they may not be valid for different societies. ${ }^{20,24}$

Despite the changes proposed by Cons et $\mathrm{al}^{8}$ and for the use of DAI in the mixed dentition, it is still the target of much criticism. ${ }^{20}$

Nevertheless, DAI is a product of extensive statistical tests and can be considered a good assessment tool to measure severity and need for orthodontic treatment also in Brazil, according to studies of consistency analysis by Cunha. ${ }^{9}$ In other words, it is considered a transcultural index, as it summarizes patterns of dental esthetics which are socially defined in the features it evaluates, ${ }^{7}$ besides providing more clinical information than other indices, not underestimating the severity of malocclusion and allowing greater category flexibility to classify the individual.
The present study was conducted in the city of Salvador, in Northeastern Brazil, a city in lack of orthodontic treatment offer in the public sector, where resources are insufficient to meet the population in need of treatment.

The population of the metropolitan region of Salvador is multiethnic, being predominant the Africanmestizo segments, i.e., there is a greater number of individuals of black or mixed ethnicity $(67.2 \%$ of the population). ${ }^{18}$ The deprivation that weaves the lives of this population in particular is also unquestionable, with regard to economic and social aspects, which are interconnected with racial issues from the country, where ethnicity contributes to a greater or lesser exposure to different health risks. This generates the hypothesis that individuals belonging to the black race would have a lower dental and medical care and suffer greater physical damage with regard to the presence of malocclusion and therefore present a greater number of individuals with need of essential orthodontic treatment compared to other ethnic groups.

However, according to the findings of this research, $24 \%$ of the studied population showed a high need for treatment, not differing from the results of studies without ethnic restriction, such as that by Abdullah and Rock, ${ }^{1}$ that found $24.1 \%$ of the population requiring orthodontic treatment. Similar results were also found in studies by Jenny et $\mathrm{a}^{16}$ which analyzed Native Americans, by Estioko, Wright and Morgan ${ }^{11}$ which evaluated Australian schoolchildren from 11 to 16 years, despite the final average score of the DAI was slightly larger in this study and by Marques et al, ${ }^{18}$ evaluating the schoolchildren aged from 10 to 14 years in Belo Horizonte, in Brazil. Compared to the DAI scores obtained by Cons et al, ${ }^{8}$ the proportion of individuals in need of orthodontic treatment was similar in this study.

In another study ${ }^{14}$ only with schoolchildren of black ethnicity from Limpopo Province, South Africa, it was observed that $26 \%$ of the individuals had severe and defined malocclusion, according to the DAI application.

The occlusal characteristics observed in the group with the highest need of orthodontic treatment were dental crowding, followed by severe maxillary overjet, corroborating the findings of Pires et $\mathrm{al}^{22}{ }^{22}$ when examining 141 schoolchildren in Salvador / BA, in addition to others. ${ }^{4,18,26}$ 
Malocclusions characterized by severe crowding and severe maxillary overjet can interfere in social relationships, since facial esthetics is considered significantly determinant in what concerns perception and attribution of society and of individuals about themselves, with dissatisfaction with appearance the main reason for seeking for orthodontic treatment. ${ }^{18}$

In what concerns age, the DAI average fell very little from 12 to 15 years. However, older individuals had a little more acceptable dental appearance than younger individuals. A decrease in the frequency of dental absence and maxillary overjet was observed. This fact probably occurred due to the fact that some younger individuals had clinical absence of some teeth, being in the 2 nd transitional period, and in the pubertal growth spurt, harmonizing the horizontal distance of the jaws. ${ }^{5}$

An increase in dental crowding with age was observed. The presence of periodontal diseases, caries and early loss of deciduous elements are facts of frequent occurrence in the poorest populations who live in a situation of lack of basic dental care. Thus, occlusal development is negatively influenced by mesial migration of teeth resulting in dental crowding. As Thilander et $\mathrm{al}^{29}$ asserts, one must not exclude the hypothesis that the lack of proper oral hygiene explains, at least partially, the high prevalence of dental crowding.

In the facial pattern of black Brazilian individuals, a predominance of maxillary double protrusion is observed, often characterized by earlier dental crowding and consequent double protrusion with labial incompetence. The current trend is the extraction of the four first premolars and maximum retraction of anterior teeth. This treatment tends to retract the lips and reduce the facial convexity.

However, the idea of correcting face convexity of the black is somewhat uncertain from the point of view of many professionals. What are the esthetic goals for these patients? Will the current esthetic values allow a slight facial convexity or that opinion has been modified by society's influence? In essence, what would be the preference of the black ethnic group, a straight or convex profile? Perhaps a middle ground situation? As society becomes increasingly concerned with the esthetic condition, orthodontists must consider the patient's opinion. The professional must consider the characteristics of the ethnic pattern since the concept of beauty is subjective, an individual matter, where only a general research cannot be applicable to all people of all ethnic groups and from different cultures.

It is impossible not to consider some limitations of the study, mainly based on the indicator used. DAI does not measure certain conditions such as overbite, midline deviation and open and posterior cross bite, clinical findings that could also be present in the analyzed individuals and often significant in severity and complexity of the case.

As the proposed design rigorously followed the requirements for achieving a representative study of schoolchildren from the city of Salvador, when extrapolating these data for the 220,300 students aged between 12 and 15 years, it is estimated that at least 52,872 schoolchildren needed orthodontic treatment. In Salvador, the public health services provided to the population does not offer this treatment. The lack of infrastructure in the political, social and operational aspects regarding the problem is clear.

\section{CONCLUSION}

Most individuals (76\%) observed in this study had little or no need for orthodontic treatment. About $24 \%$ had a condition of severe malocclusion, resulting in a vital need for orthodontic treatment.

The main occlusal characteristics found in the group with higher need for orthodontic treatment were dental crowding and severe overjet;

Age was positively related to improvement of maxillary overjet and to the presence of anterior dental crowding;

There was no statistically significant difference according to gender on the need for treatment.

The development of public policies that aim at the insertion of orthodontic treatment among procedures of health programs, with the implementation and development of specialized centers, thus, becomes essential. 
1. Abdullah MS, Rock WP. Perception of dental appearance using index of treatment need (Aesthetic Component) assessments. Community Dent Health. 2002;19(3):161-5.

2. Baume LJ. A method for measuring occlusal traits. Int Dental J. 1973:23:530-7.

3. Birkeland K, Boe OE, Wisth PJ. Relationship between occlusion and satisfaction with dental appearance in orthodontically treated and untreated groups. A longitudinal study. Eur J Orthod. 2000;22:509-18.

4. Bittencourt LP, Pimentel EC, Modesto A, Bastos E. Frequência dos hábitos orais e a severidade das maloclusões. 17ạ Reunião Anual da SBPqO; 2000; Set 2; Águas de Lindoia; 2000

5. Björk A, Skieller V. Normal and abnormal growth of the mandible. A synthesis of longitudinal cephalometric implant studies over a period of 25 years. Eur J Orthod. 1983:5(1):1-46.

6. Brook PH, Shaw WC. The development of an index of orthodontic treatment priority. Eur J Orthod. 1989:11(3):309-20.

7. Cons NC, Jenny J, Kohout FJ, Songpaisan Y, Jotikastira D. Utility of the dental aesthetic index in industrialized and developing countries. J Public Health Dent. 1989:49(3):163-6.

8. Cons NC, Jenny J, Kohout FJ. DAl: the Dental Aesthetic Index. Iowa: College of Dentistry, University of lowa; 1986. p. 134

9. Cunha ACPP. Avaliação da capacidade dos índices DAl e IOTN em estabelecer a necessidade de tratamento ortodôntico [dissertação]. Natal (RN): Universidade Federal do Rio Grande do Norte; 2002.

10. Draker HL. Handicapping labio-lingual deviations: A proposed index for public health purposes. Am J Orthod. 1960;46:295-305.

11. Estioko LJ, Wright FAC, Morgan MV. Orthodontic treatment need of secondary schoolchildren in Heidelberg, Victoria: an epidemiologic study using the Dental Aesthetic Index. Community Dent Health. 1994:11(3):147-51

12. Frazão P. Epidemiologia da oclusão dentária na infância e os sistemas de saúde [tese]. São Paulo (SP): Universidade de São Paulo; 1999

13. Grainger RM. Orthodontic treatment priority index. 1000 PHSPN (Public Health Service publication number). ed. 2, n. 25. Washington, DC Government Priting Office, 1967

14. Hlongwa P. Plessis JB. Malocclusions among 12-years-old school children in Mankweng, Limpopo Province of South Africa. SADJ. 2005;60(10):455-57.

15. Jenny J. A social perspective on need and demand for orthodontic treatment. Int Dental J. 1975:25:248-56

16. Jenny J, Cons NC, Kohout FJ, Jakobsen J. Differences in need for orthodontic treatment between Native Americans and the General Population based on DAI scores. J Public Health Dent. 1991;51:234-38.
17. López FU, Cezar GM, Ghisleni GC, Farina JC, Beltrame KP, Ferreira ES. Prevalência de maloclusão na dentição decídua. Rev Fac Odontol Porto Alegre. 2001;43(2):8-11

18. Marques LS, Barbosa CC, Ramos-Jorge ML, Pordeus IA, Paiva AM. Prevalência da maloclusão e necessidade de tratamento ortodôntico em escolares de 10 a 14 anos de idade em Belo Horizonte, Minas Gerais, Brasil: enfoque psicossocial. Cad Saúde Pública. 2005;21(4):1099-106

19. Noronha CV, Machado EP, Tapparelli G, Cordeiro TRF, Laranjeira DHP, Santos CAT. Violência, etnia e cor: um estudo dos diferenciais na região metropolitana de Salvador, Bahia, Brasil. Am J Public Health. 1999;5:4-5

20. Otuyemi D, Ogunyinka A, Dosumu $O$, et al. Percepções da estética dental nos Estados Unidos e Nigéria. Com Dent Oral Epid. 1998:26:418-20

21. Perin PCP. Prevalência de má oclusão e necessidade de tratamento ortodôntico, comparando a classificação de Angle e o Índice de Estética Dentária, na cidade de Lins/SP [tese]. Lins (SP): Universidade Estadual Paulista; 2002

22. Pires DM, Rocha MCBS, Teixeira MCT. Prevalência de oclusopatias na dentadura mista em escolares - Salvador-BA. Rev Bras Odontol. 2001:58(6):414-7.

23. Proffit WR, Fields HW, Moray LJ. Prevalence of malocclusion and orthodontic treatment need in the United States: estimates from the NHANES III survey. Int J Adult Orthodon Orthognath Surg. 1998;13(2):97-106.

24. Saltzmann JA. Handicapping malocclusion assessment to establish treatment priority. Eur J Orthod. 1968:54:749-65.

25. Shaw WC, Lewis HG, Robertson NRE. Perceptions of malocclusion. Br Dent J. 1975:138:211-6.

26. Silva Filho OG, Freitas SF, Cavassan AO. Prevalência de oclusão normal e má oclusão na dentadura mista em escolares da cidade de Bauru (São Paulo). Rev Assoc Paul Cir Dent. 1989;43(6):287-90

27. Silva CHT, Araújo TM. Prevalência de más oclusões em escolares na Itha do Governador, Rio de Janeiro. Parte 1: Classes I, II e III e mordida cruzada. Ortodontia. 1983;16(3):10-6

28. Summers CJ. The Occlusal Index: A system for identifying and scoring occlusal disorders. Am J Orthod. 1971;59(6):552-67

29. Thilander B, Pena L, Infante C, Parada SS, Mayorga C. Prevalence of malocclusion and orthodontic treatment need in children and adolescents in Bogotá, Colômbia. An epidemiological study related to different stages of dental development. Eur J Orthod. 2001:23:153-67.

30. World Health Organization. Oral health surveys: basic methods. $4^{\text {th }}$ ed Geneva: ORH/EPID; 1997 